\title{
Die frekwensie van laat voltooiing op bouprojekte in die Republiek van Suid-Afrika
}

\author{
C.H. Klopper en D.G. Brümmer \\ Departement Bourekenkunde en Konstruksiebestuur, Universiteit van Pretoria, Pretoria
}

Ontwang 17 Februarie 2000; anvaar 17.Junie 2000

\section{UITTREKSEL}

"I Ondersoek is geloods om te bepaal of bouprojekte in die Republick van Suid-Afrika oor die algemeen betyds voltooi word en, indien dit nie die geval is nie, wat die impakpotensialal van laat voltooiing vir die partye tot die boukontrak inhou.

Die navorsingsresullate is wat moontlik gekwantifiseer en in verskeie tabelformate angebied. Die interpretasies van hicrdie resultate en die bevindings is in detail behandel. Die inhoud van die tabell', wat op groot hoeveelhede data gebaseer is, en die resultate, wat omvangryke verwerkings verteenwoordig, is van so "n atard dat 'n geskrewe omskrywing datarvan nie altyd die aangewese metode van a anbieding sou wees nie. Derhalwe is resultate ook in verskeie gevalle met behulp van grafiese voorstellings verder. toegelig.

Vamuit die interpretasie van die verwerkte data en bevindinge is gevolgtrekkings gematak dat die omvang van vertragings op en die gevolglike laat voltooiing van bouprojekte in die RSA groter is as wat algemeen aamvar word en dat die potensiële gevolge dararvan wesenlike hoë risiko's vir die partye tot die boukontrak inhou.

\begin{abstract}
The occurrence of late completion on building projects in die Republic of South Africa

An investigation was lanched to determine whether building projects in the Republic of South Africa are generally completed timeously and, if that is not the case, what the potential impact of late completion holds for the parties to the contract.

The research results are quantified where possible and are presented in varions tabular formats. The interpretation of these results and the consequent findings are dealt with in detail. The content of the tables, which are based on large quantities of data, and the results, which represent extensive processing, are of such a nature that they cannot always be presented effectively in written form. For this reason graphic illustrations of results have been included in several instances.

On the basis of the interpretation of the processed data and findings, it was concluded that the extent of delays on and the resulting late completion of building projects in the RSA is higher than generally accepted and that the potential results of delays contain real risks to the parties to the building contract.
\end{abstract}

\section{SLEUTELWOORDE}

Vertraging, verlenging, konstruksietydperk, beplanning, tyd

\section{AGTERGROND}

\subsection{Inleiding}

Die kontraktucle voltooiingsdatum van 'n bouprojek maak decl uit van die essentialia van die kontrak en is seker een van die belangrikste mylpale wat die aannemer moct haal in dic uitvocring van die werke. Die suksesvolle bereiking van hierdie mylpaal bepaal ook telkens in 'n groot mate die sukses, al dan nic, van die projek. In die literatuur is dalar verskeie verwysings na vertragings en gevolglike verlenging van konstruksietydperke op bouprojekte, en meer spesifick die negatiewe gevolge daarvan op dic onderskeic kontrakterende partye. Die frekwensic en omvang van sodanige vertragings in dic Republick van Suid$\Lambda$ frika (RS $\Lambda$ ) is egter nog nooit op ' $n$ wetenskaplik verantwoordbare wyse vasgestel nie.

Dit kan vir 'n bouheer van groot waarde wees indien die frekwensic en omvang van laat voltooiing van bouprojekte in Suid- $\wedge$ frika bekend is, aangesien hierdie inligting 'n direkte invloed kan hê op die keuse en samestelling van die konsultantespan wat hy vir 'n bepaalde bouprojek beoog. Die konsultan- tespan, in samewerking met die bouhecr, mag op hulle beurt weer hierdeur beinvloed word wanneer die keuse van die kontrakstrategic wat gevoly behoort te word, uitgeoefen word.

Die doel met hicrdic artikel is hoofsalaklik om die frekwensic cn omvang van laat voltooiing van bouprojekte in dic RS $\wedge$ aan te dui.

\subsection{Aflsakening}

1.2.1 Hierdic studic is tot dic boubedryf in dic RS $\wedge$ beperk.

1.2.2 Die data wat versamel is vir die oplossing van hierdie probleem is beperk tot geselekteerde bouprojekte wat vir die Departement van Openbare Werke opgerig is.

\section{AANDUIDINGS UIT DIE LITERATUUR VAN DIE OMVANG VAN LAAT VOLTOOIING VAN BOU. PIROJEKTE}

Met verwysing na laat voltooing van bouprojekte maak James R. Knowles en Binnington Copeland' die volgende stelling:

* Outeur anal wie korrespondensic gerig kan word.

Ilierdie artikel is 'n verkorte weergan'e van 'n onderifleling van 'n studie getiteld "Die besthur van vertragings en die gevolglike verlenging van konstruksietydperke op bouprojekte in die Republiek van Suid-Afika" deur Diederick Gerhardus Briümmer; voorgele ler vervulling van 'n deel van die vereistes vir die graad Philosophiae Doctor in die Fakulteit Natumwetenskappe, Universiteit van Pretoria, onder die promotorskap van prof. di: C.II. Klopper. Vir meer besonderhede soos byvoorbeeld geografiese verskille, verskille tussen tydvakke, verskille tussen soorte bouprojekte en dies meer word lesers na die procfskrif verwys. 
Extensions of time provisions and their application cause more disputes than almost any other aspect of building and civil engineering contracts.

H.M. Hohns ${ }^{2}$ ondersteun hierdie opinie en gee verder soos volg 'n aanduiding van die omvang van die eise betrokke by tydverwante dispute:

Those involved in a construction problem quickly learn that it is not hard (or the nuts and bolts) dollars which are important, rather it is in the time-related costs that the huge damages arise to all concerned.

Alhoewel bogemelde outeurs vaste menings in hierdic verband huldig, is dic klaarblyklike afwesigheid van behoorlike wetenskaplike ondersocke na die laat voltooiing van bouprojekte steeds 'n leemte. In die lig hiervan berus die bestaande kennis in hierdic verband bloot op die crvarings en persepsies van enkele persone en gevolglik is gegewens vaag en fragmentaries.

\section{BEPALING VAN KONSTRUKSIETYDPERKE VIR BOUPROJEKTE}

Aannemers kan deur middel van die toepassing van geskikte beplanningstegnicke en met inagneming van die nodige hulpbronne dic projekuitvocring sodanig beplan dat hulle dic werk binne enige redelike gegewe konstruksietydperk kan voltooi. Min literatuur bevat egter enige inligting ten opsigte van dic bepaling van konstruksictydperke op bouprojekte. Informele waarneming laat dic vermoede ontstaan dat hicrdic belangrike aspek oor die algemeen op 'n lukrake wyse deur dic boukundige professies hanteer word.

\section{NAVORSINGSMETODIEK VIR DIE STUDIE GEBIRUIK} Elke bouprojek is unick. Buiten algemeen bekende verskille soos ondergrondse omstandighede, weersomstandighede en ligging, speel faktore soos aannemers, professionele konsultante, kontrakvoorwaardes, dic ckonomic en die owerhede clkeen 'n belangrike rol in die tydige en suksesvolle afhandeling van kontrakte, al dan nic. Boonop is dic proses van oprigting van bouprojekte 'n multimiljocnrand-bedryf. Dit spreck derhalwo vanself dat bouprojekte nic praktics in 'n laboratorium of in 'n klein hantecrbare formaat vir die docleindes van 'n studic van hierdie aard gesimuleer kan word nic.

Daar is gevolglik besluit om ex post facto-navorsing op beskikbare geskikte data van afgehandelde bouprojekte met hocveclheidslyste as kontrakgrondslag, te doen.

\section{DATA}

\subsection{Aard en omvang van data}

Vir elke bouprojek wat by hierdic opname ingesluit is, is die volgende data bekom:

5.1.1 Kontrakbedrag

5.1.2 Tendersluitingsdatum

5.1.3 Datum van aanvaarding van tender

5.1.4 Beplande voltooiingsdatum

5.1.5 Voltooiingsdatum (datum van ecrste oorname)

5.1.6 Die toepaslike boukoste-indekse verkry van dic Buro vir Ekonomiese Ondersoek, Universiteit van Stellenbosch (BEO) vir die herleiding van kontrakbedrae na 'n gemeenskaplike datum vir vergelykingsdocleindes.

\subsection{Bronne en versameling van data}

5.2.1 Bouprojekte in dic RSA kan op dic basis van eicnaarskap in twee hoofkategorieë verdeel word, naamlik dic private sektor en die openbare sektor. Daar bestaan geen geskikte sentrale databank wat die benodigde inligting bevat ten opsigte van bouprojekte in die private scktor nic. Die inligting wat nodig is vir' 'n sinvolle steckprocfgrootte is tussen talle eiendomseienaars landswyd versprei. Verder is projekdata nic maklik bekombaar nic omdat eiendomseienaars oor dic algemeen onwillig is om sodanige inligting te verskaf. Daar is derhalwe besluit om data van openbare liggame te versamel. Dic kontrakvoorwaardes gebruik en die metodes voorgeskryf deur die nasionale, provinsiale en plaaslike owerhede verskil van mekaar, derhalwe is daar besluit om die inwin van data tot openbare liggame, wat op 'n nasionale vlak akticf is, te beperk.

5.2.2 Dit het aan die lig gekom dat die Departement Openbare Werke reeds ongeveer 15 jaar gelede 'n rekenaarstelsel in bedryf gestel het en steeds onderhou, naamlik dic Werke-beheerstelsel (WBS), walarvolgens sekere data ten opsigte van alle konstruksieprojekte, wat deur hierdic departement uitgevoer word, op rekord geplaas word. Ongeveer ses-en-twintigduisend projekte is reeds op hierdie stelsel geregistreer.

Die data soos in 5.1 uiteengesit, is vanuit die gemelde databasis versamel.

Die beperkinge waarbinne dic steckprocf uitgevoer moes word, is soos volg geformulecr:

(a) Alleenlik inligting van bouprojekte met hocveclheidslyste as kontrakgrondslag moes versamel word.

(b) Bouprojekte met konstruksietydperke van korter as ses maande moes geïgnoreer word.

(c) Dic voltooiingsdatum vir elkc bouprojck moes reeds bereik gewees het.

Bogemelde bouprojekte is deur middel van programmeringstegnicke afgebaken en die nodige data is vanuit dic databasis onttrek. Dic finale steekproefgrootte het sewehonderd-en-elf bouprojekte ingesluit.

\subsection{Verwerking van data}

5.3.1 Dic toepaslike boukoste-indekse soos deur die BEO voorsien, is tecnoor elke afsonderlike bouprojek aangeteken.

5.3.2 Ten cinde dic bouprojekte in monetêre terme vergelykbaar te maak, is dic kontrakbedrac na 'n bepaalde gemeenskaplike datum aangepas deur van dic gemelde boukosteindekse gebruik te maak. Hicrdic datum is arbitrêr as Januaric 1998 gekies en dic beraamde BEO-indekse voorsien deur dic bou-ekonome, Medium-Term Forecasting Associates (MFA) ${ }^{3}$ (Februaric 1998-uitgawe), is toegepas

5.3.3 Die volgende berekeninge is met behulp van die data uitgevoer:

5.3.3.1 Die oorspronklik beplande konstruksictydperk in kalenderdac, dit is: Beplande voltooiingsdatum minus Datum van aanvaarding van tender, plus 1 .......(A).

5.3.3.2 Die werklike konstruksictydperk in kalenderdac, dit is: Voltooiingsdatum (datum van eerste oorname) minus Datum van aanvaarding van tender, plus 1..(B).

5.3.3.3 Dic oorskryding van die beplande konstruksictydperk in kalenderdac, dit is: B minus $A$. Indien dic resultaat negaticf was, is nul (0) dac vertraging getoon.........(C).

5.3.3.4 Dic getal bouprojekte wat betyds voltooi is, dit is dic gevalle waar $\mathrm{C}=$ nul $(0)$. Dic getal bouprojekte wat die beplande konstruksictydperk oorskry, dit is dic gevalle waar $\mathrm{C}$ 'n positiewe resultaat vertoon.

5.3.3.5 Die omvang van die oorskryding van die beplande konstruksietydperk uitgedruk as 'n persentasie van die beplande konstruksietydperk wat wiskundig soos volg 
uitgedruk kan word : [C/ $/ \wedge \times 100]$, waar $\Lambda \mathrm{cn} C$ dic waardes soos hierbo uiteengesit, verteenwoordig.

$\Lambda$ angesien gemelde persentasies tussen data van 'n relaticwe groot steckprocf versprei is en om die interpretasies daarvan meer sinvol te mak, is op die volgende groeperinge besluit :

5.3.3.5.1 Gebaseer op dic omvang van dic oorskryding:

(a) $0 \%$ oorskryding (voltooiing binne dic oorspronklik beplande konstruksictydperk);

(b) hoogstens 10\% oorskryding van dic oorspronklik beplande konstruksictydperk;

(c) meer as $10 \%$ en hoogstens $25 \%$ oorskryding van die oorspronklik beplande konstruksietydperk;

(d) meer as $25 \%$ en hoogstens $50 \%$ oorskryding van dic oorspronklik beplande konstruksietydperk;

(e) meer as $50 \%$ en hoogstens $100 \%$ oorskryding van die oorspronklik beplande konstruksietydperk; en

(f) meer as $100 \%$ oorskryding van dic oorspronklik beplande konstruksietydperk.

5.3.3.5.2 Gebaseer op die beraande kontrakbedrac (R-waarde: Januarie 1998):

(a) R 0 tot R I 000000 ;

(b) R 1000001 tot R 5000000 ;

(c) R 5000001 tot R 15000000 ; en

(d) R 15000001 en groter.

5.3.4 Die volgende betekenis is geheg aan die afkortings ensovoorts wat gebruik word in die tabelle en figure wat hierna volg: $\mathrm{S} A$ (of Suid- $\Lambda$ frika) $=$ Republick van Suid- $\Lambda$ frika
$\mathrm{n}$
$=$ Getal bouprojekte
BETYDS VOLTOOI
$=$ Kyk 5.3.3.5.1 (a)
BETYDS+0-10\% LAAT
BETYDS $+0-25 \%$ LAAT
$=$ Kyk 5.3.3.5.1 (b)
BETYDS $+0-50 \%$ LAAT
$=\mathrm{Kyk} 5 \cdot 3 \cdot 3.5 .1(\mathrm{c})$
$=$ Kyk 5.3.3.5.1 (d)
BETYDS+0-100\% LA $\mathrm{TT}=\mathrm{Kyk}$ 5.3.3.5.1 (c)
BETYDS+0-100\%+ LAAT $=$ Kyk 5.3.3.5.1 (f)
R0 - IM
$=\mathrm{Kyk}$ 5.3.3.5.2 (a)
R1 - 5M
$=$ Kyk 5.3.3.5.2(b)
R5 - 15M
$=$ Kyk 5.3.3.5.2(c)
R $15 \mathrm{M}+$
$=$ Kyk 5.3.3.5.2 (d)

\section{INTERPRETASIE VAN DATA EN BEVINDINGE}

6.1 Dic gemiddeld vir $A, B, C$ en gemiddelde Persentasie oorskryding van die konstruksietydperk, ooreenkomstig 5.3.3 hiervan, is in tabel 1 aangedui. Dic regterkantste kolom gemerk $C / A$, dui dic gemiddelde persentasic aan waarmec bouprojekte die oorspronklik beplande konstruksictydperke oorskry.

6.1.1 Dic oorspronklik beplande konstruksietydperk word met gemiddeld $25,1 \%$ oorskry. Indien in gedagte gehou word dat bouprojekte wat wél binne die oorspronklik beplande konstruksietydperk voltooi is, decl van hierdie oefening uitmaak, word besef dat 'n wesenlike gedeclte van hierdie bouprojekte uiters laat afgehandel is.

6.2 Om dic omvang van die oorskryding van dic oorspronklik beplande konstruksietydperk op bouprojekte verder toe te lig, is die inligting soos in 5.3.3.5 hicrvan uiteengesit, geimplementeer. Die volgende tabel is vir hierdic doel voorberei (kyk tabel 2).

6.3 Dic syfers vervat in tabel 2 dui dic getal bouprojekte betyds of laat voltooi aan, uitgedruk as 'n persentasic van dic steckproef vir elke afsonderlike kategoric.

6.4 Noukeurige studic van dic resultate van dic verwerkte data, soos in tabel 2 vervat, lei tot die volgende bevindinge:

6.4.1 Bouprojekte binne die oorspronklik beplande konstruksietydperk voltooi:

6.4.1.1 Op slegs 173 uit 711 bouprojekte $(24,3 \%)$ is hierdic oorspronklike doelwit bereik. Dit kan omgekeerd gestel word dat $75,7 \%$ bouprojekte eers op latere stadia voltooi is, soos hierna meer volledig aangedui word.

6.4.1.2 Bouprojekte in kategorië̈ van klein na groot in monetêre terme geklassifisecr:

Hoër frekwensies kleiner bouprojekte word binne die oorspronklik beplande konstruksictydperk voltooi as in die geval van groter bouprojekte. (Kyk figuur 1 vir 'n duidelike uitbeelding van hierdic tendense.)

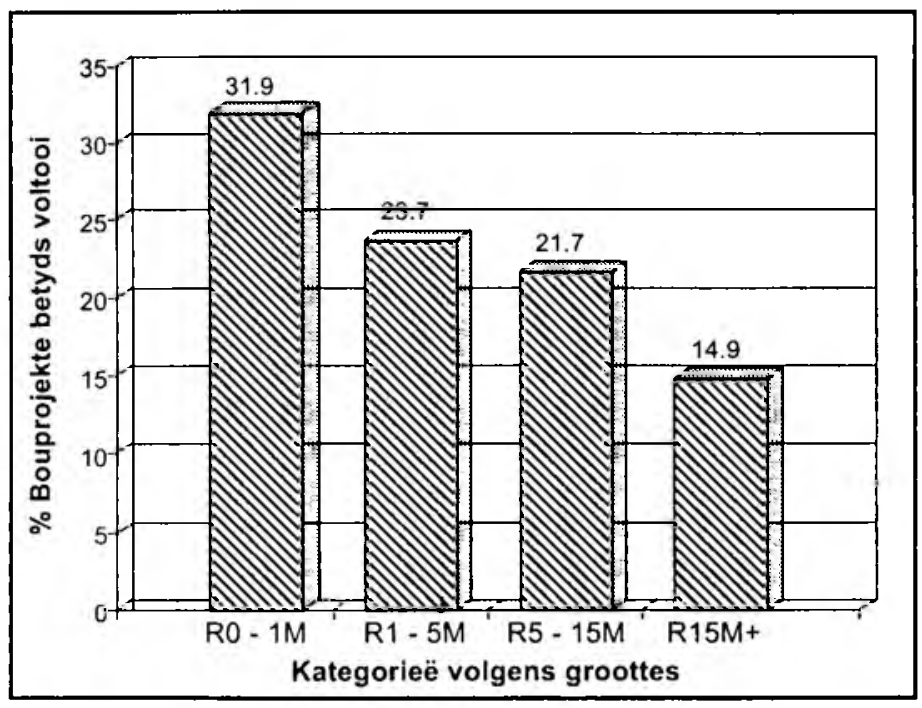

Figuar 1: Suid-Afrika: Grafiese voorstelling van die persentasie bouprojekte wat binne die oorspronklik beplande konstruksietydperk vollooi word.

Tabel 1 Oorskryding van die oorspronklik beplande konstruksietydperk

\begin{tabular}{|l|c|c|c|c|}
\hline GEBIED & $\begin{array}{c}\text { A } \\
\text { (DAE) } \\
\text { (Gemiddeld) }\end{array}$ & $\begin{array}{c}\text { B } \\
\text { (DAE) } \\
\text { (Gemiddeld) }\end{array}$ & $\begin{array}{c}\text { C } \\
\text { (DAE) } \\
\text { (Gemiddeld) }\end{array}$ & $\begin{array}{c}\text { C/A } \\
\text { (\%) }\end{array}$ \\
(Gemiddeld)
\end{tabular}

Tabel 2 Persentasie bouprojekte betyds voltooi $(n=173)$

\begin{tabular}{|l|c|c|c|c|c|}
\hline GEBIED & $\begin{array}{c}\text { ALLE } \\
\text { PROJEKTE }\end{array}$ & $\begin{array}{c}\text { RO TOT R1 } \\
\text { MILJOEN }\end{array}$ & $\begin{array}{c}\text { RI TOT R5 } \\
\text { MILJOEN }\end{array}$ & $\begin{array}{c}\text { R5 TOT R15 } \\
\text { MILJOEN }\end{array}$ & $\begin{array}{c}\text { R15 } \\
\text { MILJOEN + }\end{array}$ \\
\hline Suid-Afrika $(n=711)$ & 24,3 & 31,9 & 23,7 & 21,7 & 14,9 \\
\hline
\end{tabular}


6.5.1 Bouprojekte ná die oorspronklik beplande konstruksietydperk voltooi:

Tabel 2 is uitsluitlik opgestel om bouprojekte wat binne die oorspronklik beplande konstruksietydperk voltooi is, te bestudeer. Om te bepalal wanneer die balans van die bouprojekte, wat eers ná die oorspronklik beplande konstruksietydperk voltooi is, uiteindelik afgehandel is, is tabel 3 voorberei.

Gemelde tabel weerspicël, onder andere, die kumulatiewe persentasies voltooide bouprojekte in dic kategoricë van voltooiing soos in 5.3.3.5.1 uiteengesit. Nadat studies op die rekenaar uitgevoer is (verskeie grafiese voorstellings is op dic monitorskerm bestudeer), is hierdic gedeelte van dic aanbieding tot die bespreking wat hicrna volg, beperk.

6.5.1.1 Bouprojekte in kategorieë van klein na groot in monetêre terme, geklassifisecr:

Onder 6.4.1.2 is aangedui dat groter getalle kleiner bouprojekte binne dic oorspronklik beplande konstruksictydperke voltooi is as wat die geval is met groter bouprojekte. 'n Noukeurige studic van die resultate wat weens dic omvang daarvan nic in hicrdic artikel uitcengesit kan word nic, toon aan dat groter bouprojekte gemelde agterstand kort na dic oorspronklik beplande konstruksietydperk inhaal, selfs verbysteck en in dic algemeen nie so lank as klein bouprojekte in terme van tyd uitgerek is nie. (Vir 'n duidelike voorstelling van hierdie tendense word na figuur 2 verwys.)

\section{GEVOLGTREKKINGS}

Dic volgende gevolgtrekkings word gemaak ten opsigte van:

7.1 Die omvang van oorskrydings van die oorspronklik beplande konstruksietydperke op bouprojekte in die algemeen:

7.1.1 Die oorspronklik beplande konstruksictydperke op bouprojekte in dic algemeen word met aansienlike lang tydperke oorskry. Die omvang van die probleem is sodanig dat die potensiële gevolge daarvan vir albci kontrakterende partye wesenlike hoë risiko's inhou.

7.2 Bouprojekte wat binne die oorspronklik beplande konstruksietydperke voltooi word:

7.2.1 'n $\Lambda$ ansienlike hoeveclheid bouprojekte word nic binne dic oorspronklik beplande konstruksietydperke voltooi nic. Dic omvang van dic problecm is sodanig dat dic potensiële gevolge daarvan dic doelwitte van albei kontrakterende partye bedreig omdat dit vir beide wesenlike hoë risiko's inhou.

7.2.2 'n $\Lambda$ ansienlike hoeveclheid meer kleiner bouprojekte word binne die oorspronklik beplande konstruksietydperke voltooi as wat die geval met groter bouprojekte is.

7.3 Bouprojekte wat na die oorspronklik beplande konstruksietydperke voltooi word:

7.3.1 In 7.2.2 is aangedui dat groter getalle kleiner bouprojekte binne die oorspronklik beplande konstruksictydperke voltooi word as wat die geval is met groter bouprojekte. Met groter bouprojekte word gemelde agterstande egter kort na dic verstryking van dic oorspronklik beplande konstruksictydperke uitgewis en vertoon daarna beter as kleincr bouprojekte.
Dic vraag is now of dic antwoorde wat verkry is en afleidings wat gemaak is vanuit gemelde data beperk is tot die milieu wat direk aan die geselekteerde populasie behoort, of kan belangrike afleidings en gevolgtrekkings vir bouprojekte op 'n breër basis in dic RS $\Lambda$ hicruit gemaak word? Gemelde bouprojekte word met die uitsondering van die bouheer deur dieselfde boukundige professies hanteer en deur dieselfde aannemerskorps opgerig as wat die geval vir ander bouprojekte in Suid- $\wedge$ frika is. Die aanname kon derhalwe gemaak word dat die bevindinge en gevolgtrekkings wat gemaak is ook op bouprojekte in dic privaat scktor van tocpassing sal wees. Dit dien vermeld te word dat 'n doktorale proefskrif deur C.P. de Lecuw, ${ }^{4}$ waarin die vooruitberaming van konstruksietydperke van bouprojekte onder andere ondersock is, bevindinge gemaak is wat hierdic standpunt ondersteun.

Dit dien verder vermeld te word dat hierdie bevindinge daartoe gelei het dat verdere studies noodwendig uitgevoer moes word. Die omvang van vertragings, wat deur individuele faktore elk afsonderlik op bouprojekte veroorsaak word, is ook ondersock. Met behulp van die ontleding van antwoorde op vraclyste wat aan gekeurde respondente gerig is, is ondersoek of die dienste van 'n onathanklike beplanningskonsultant aangewend sou kon word om in die beplanning en skedulering, sowel as die uitvocring van dic werke, die behoeftes/vereistes van beide dic bouheer en dic aannemer te ondervang. ' $n$ Mecr wetenskaplik verantwoordbare wyse vir die toedeling van die eicnaarskap van speling (Engels: float) op bouprojekte en die wenslikheid van sodanige stappe, al dan nic, word op 'n soortgelyke manier ondersock. Die omvang van gemelde studies is egter sodanig dat dit in verdere artikels behandel kan word.

\section{DEFINISIES}

Konstruksietydperk: Die tydperk wat strek vanaf die datum van aanvaarding van tender tot en met die datum van eerste oorname soos in die Departement van Openbare Werke: Kontrakvoorwaardes (OW 676), ${ }^{5}$ klousules 20 en 2 I omskryf.

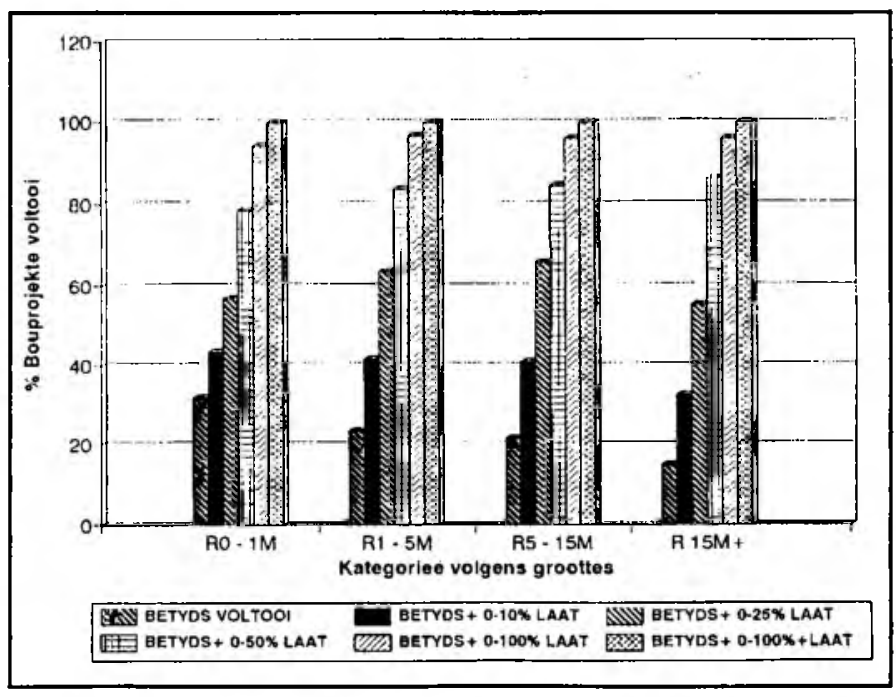

Figuur 2: Suid-Afrika: Grafiese voorstelling val die persentasie bouprojekte op verskillende stadia van tyd voltooi.

Tabel 3 Persentasie bouprojekte op bepaalde stadia voltooi

\begin{tabular}{|l|c|c|c|c|c|c|}
\hline GEBIED & BETYDS & B + 0-10\% L & B + 10-25\% L & B + 25-50\% L & B + 50-100\% L & B + 0-100\% + L \\
\hline Suid- $\Lambda$ frika $(n=711)$ & 24,3 & 40,6 & 61,0 & 82,7 & 95,8 & 100,0 \\
\hline
\end{tabular}




\section{SUMMARY}

$\wedge \mathrm{n}$ investigation was launched to determine whether building projects in the RSA are generally completed timeously and, if that is not the case, what the potential impact of late completion would be for the parties to the contract.

By means of ex post facto research on available data of completed building projects it was possible to arrive at the following conclusions:

1. The order of magnitude of timeous completion and the excess beyond the original planned construction periods in general:

1.1 The construction periods originally planned for building projects are generally exceeded by fairly long periods. The potential consequences of late completion involve real risks to both contracting parties.

2. Building projects completed within the originally planned construction periods:

2.1 $\Lambda$ considerable number of building projects are not completed within the originally planned construction periods. The magnitude of the problem is such that the potential consequences of late completion represent a real threat to the objectives of both contracting parties because it places both at considerable risk.

2.2 Significantly more smaller building projects are completed within the originally planned construction periods than is the case with larger building projects.

3. Building projects completed after the originally planned construction periods:

3.1 It is indicated in 2.2 that significantly more smaller building projects are completed within the originally planned construction periods than is the case with larger building projects. However, in the case of the latter, the stated back-

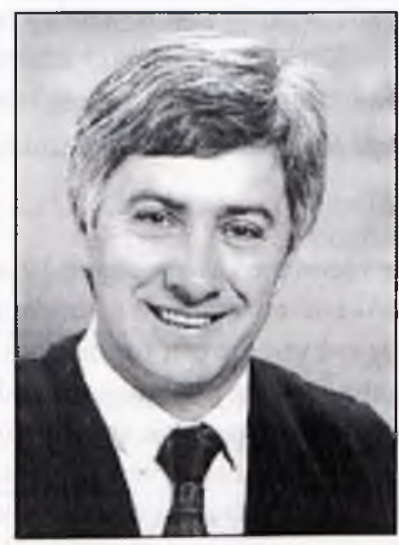

log is made up shortly after expiry of the originally planned construction periods and results over time are better than in the ease of smaller building projects.

It needs to be stated that the results established by this study have prompted investigations. The extent of delays caused by individual factors on building projects, each treated as a separate entity, were investigated. By means of an analysis of answers to questionnaires completed by selected respondents, an attempt was made to determine whether the services of an independent planning consultant could be utilised in the planning, scheduling and execution of the works, to ensure that the needs/ requirements of both the employer and the contractor could be met. $\Lambda$ more scientifically accountable way of allocating the ownership of float on building projects and the desirability of such action were investigated in a similar way. However, the nature and extent of these studies are of such magnitude that they fall outside the scope of this article.

\section{LITERATUURVERWYSINGS}

1. Knowles, J.R., Binnington Copcland \& Associates. (1995). All you need to know about Construction Claims (Document relcased during a scminar).

2. Hohns, H.M. (1979). Preventing and Solving Construction Contract Disputes (Van Nostrand Reinhold, New York).

3. Mcdium Term liorccasting Associates Building Economists. (February 1998). Revision of the CPAP (Haylett Formula), BER building cost index and P0153 (P28) index forecasts (Medium Term Forecasting Associatcs CC, Stcllenbosch).

4. De Lecuw, C.P. (1988). Voonvitberaming van vergoeding betaalbaar ingevolge die Bounywerheidsadviesraad se Kontrakprysanpassingsbepalings [D.Sc. (Bourckenkunde), Universitcit van Pretoria].

5. Departcment van Openbarc Werke. Kontrakvoorwaardes (OW 676) (Staalsdrukker, Pretoria).

Gerhard Brïmmer is medeprofessor en programleier vir Bourekenkunde in die Departement Bourekenkunde en Konstruksiebestuur aan die Universiteit van Pretoria, waar hy ook sy Ph.D.-graad verwerf het. Hy is 'n geregistreerde bourekenaar en lid van die Vereniging van Suid-Afrikanse Bourekenaars (VSAB). Hy dien in die bestuur van die VSAB en verteenwoordig hulle in verskeie gesamentlike komitees in die konstruksiebedryf. Sy praktykondervinding sluit 'n wye spektrum van volledige bourekenaarsdienste in soos die voorsiening van kantoor- en universiteitsgeboue, brouery-installasies en dispuntskikking. As 'n inisiatief van die Heropbou- en Ontwikkelingsprogram (HOP) het die Departement van Openbare Werke hom aangestel as leier van 'n taakgroep wat opleiding met boukontrakte integreer: 